\title{
Breakdown of Host Resistance by Independent Evolutionary Lineages of Beet necrotic yellow vein virus Involves a Parallel C/U Mutation in Its $p 25$ Gene
}

\author{
Rodolfo Acosta-Leal, Becky K. Bryan, Jessica T. Smith, and Charles M. Rush
}

Texas AgriLife Research, Texas A\&M University System, Amarillo 79106.

Accepted for publication 25 September 2009.

\begin{abstract}
Acosta-Leal, R., Bryan, K. B., Smith, J. T., and Rush, C. M. 2010. Breakdown of host resistance by independent evolutionary lineages of Beet necrotic yellow vein virus involves a parallel C/U mutation in its $p 25$ gene. Phytopathology 100:127-133.

Breakdown of sugar beet $R z 1$-mediated resistance against Beet necrotic yellow vein virus (BNYVV) infection was previously found, by reverse genetics, to be caused by a single mutation in its $p 25$ gene. The possibility of alternative breaking mutations, however, has not been discarded. To explore the natural diversity of BNYVV in the field and its effects on overcoming $R z 1$, wild-type (WT) and resistance-breaking (RB) p25 genes from diverse production regions of North America were characterized. The relative titer of WT $p 25$ was inversely correlated with disease expression in $R z 1$ plants from Minnesota and California. In
\end{abstract}

ABSTRACT
Minnesota, the predominant WT $p 25$ encoded the $\mathrm{A}_{67} \mathrm{C}_{68}$ amino acid signature whereas, in California, it encoded $\mathrm{A}_{67} \mathrm{~L}_{68}$. In both locations, these WT signatures were associated with asymptomatic BNYVV infections of $R z 1$ cultivars. Further analyses of symptomatic resistant plants revealed that, in Minnesota, WT $\mathrm{A}_{67} \mathrm{C}_{68}$ was replaced by $\mathrm{V}_{67} \mathrm{C}_{68}$ whereas, in California, WT $\mathrm{A}_{67} \mathrm{~L}_{68}$ was replaced by $\mathrm{V}_{67} \mathrm{~L}_{68}$. Therefore, $\mathrm{V}_{67}$ was apparently critical in overcoming $R z 1$ in both pathosystems. The greater genetic distances between isolates from different geographic regions rather than between WT and RB from the same location indicate that the underlying $\mathrm{C}$ to $\mathrm{U}$ transition originated independently in both BNYVV lineages.

Additional keywords: Beet soilborne mosaic virus, Benyvirus, convergent evolution, rhizomania.
To overcome plant resistance genes, viruses generally need to replicate under restrictive host conditions to incorporate adaptive genetic changes. The type, number, order, and speed of these viral changes impact plant resistance durability (3). Although most resistance $(R)$ genes deployed against virus infections have lasted more than 25 years in the field (7), the effectiveness of $R z 1$, which confers partial resistance against Beet necrotic yellow vein virus (BNYVV), the causal agent of rhizomania in sugar beet, has been compromised by the reemergence of the disease after 15 years of commercial field deployment of $R z 1$ in North America $(18,19,27)$.

The Benyvirus BNYVV is a multipartite, single-stranded, positive-sense RNA virus. RNA-1 and -2 encode the essential elements for replication, encapsidation, and cellular translocation, whereas RNA-3, -4, and isolate-specific, RNA-5, encode proteins involved in pathogenesis, vector transmission, and suppression of gene silencing $(17,25,31)$. Despite its divided genome and the potential of mixed infections with different strains (13), high genetic stability seems to be the norm between spatiotemporally separated populations (11). In an otherwise genetically stable BNYVV genome, p25 (encoded by RNA-3) and p26 (RNA-5) genes are the most variable genomic regions, with strong positive selection acting on some of their codons (28). These genes operate synergistically to exacerbate symptoms in certain sugar beet cultivars $(10,17)$, although $p 25$ accounts for most rhizomania expression (32).

Rhizomania is characterized by profuse lateral root proliferation, taproot constriction, root necrosis, and leaf chlorosis without

Corresponding author: C. M. Rush; E-mail address: crush@ag.tamu.edu

doi:10.1094/PHYTO-100-2-0127

(c) 2010 The American Phytopathological Society foliar virus infection. The resistance mechanisms governed by $R z 1$ are phenotypically expressed by restricting virus accumulation in taproots and suppressing rhizomania development (32). At the biochemical level, resistance is associated with differential expression of genes involved in pathogenesis and hormonemediated plant development $(4,15,29)$. Despite these plant defense responses, BNYVV still accumulates at low levels in asymptomatically infected roots of $R z 1$ plants.

By reverse genetics, Koenig et al. (12) demonstrated, that for European A type isolates E12 and S8, valine at position 67 of the BNYVV p25 protein is required to overcome $R z 1$-mediated resistance and allow normal virus replication. This amino acid substitution was previously associated with breakdown of $R z I$ in field-infected plants from the California Imperial Valley (CIV) (2). However, Liu and Lewellen (18) did not find a correlation between $p 25$ sequences of numerous North American isolates and their titer in soil-inoculated $R z l$ plants in greenhouse assays. This observation suggested that BNYVV might mutate in different ways to overcome $R z l$ in North America. Therefore, the objective of this work was to explore the genetic diversity of the BNYVV p25 gene that might be associated with expression of rhizomania in $R z 1$ plants in the field.

\section{MATERIALS AND METHODS}

Field sampling. For initial investigation of BNYVV sequences, the virus was baited from field soil samples as described by Acosta-Leal and Rush (2). These infested soil samples, some of which had been collected as early as 1991, were from the rhizosphere of symptomatic and asymptomatic $R z 1$ plants, and symptomatic susceptible ( $r z l)$ plants from different sugar beet production regions around the United States. The name of these isolates provides information about their origin (i.e., field name, when it 
was known, state, and collection year). BNYVV rarely infects the aerial part of sugar beet plants but root-infected plants normally develop upright leaves with generalized chlorosis during maturation. This foliar symptom facilitates identification of plants with rhizomania, which frequently have a cluster distribution in the field (27). For virus quantification and genotyping using TaqManspecific probes, four to six $R z l$ plants were collected from both inside and outside a yellow patch of plants with rhizomania and individually analyzed for virus infection. Each sample consisted of $\approx 0.1 \mathrm{~g}$ of diseased hairy roots, or normal lateral roots from those plants without any root expression of the disease. Samples from Minnesota (MN) were from Crookston (four fields, 2005), Willmar (seven fields, 2005), and Roseland (one field, 2007), whereas samples from CIV were from four fields surveyed in 2006.

Total RNA extractions. Root samples were collected in 2-ml microfuge tubes that contained a sterile 4-mm stainless steel grinding ball and then stored at $-80^{\circ} \mathrm{C}$ until processing. During RNA extraction, the plant tissue was first powdered by immersing the unopened 2-ml tubes containing the sample in liquid nitrogen and then immediately shaking them at 1,600 rpm for $2 \mathrm{~min}$ in a Talboys high-throughput homogenizer (Thorofare, NJ). Then, total RNA was extracted following the RNeasy Plant Mini Kit (Qiagen, Inc., Valencia, CA) protocol. All filtrations and filter drying were performed by centrifugation at $16,000 \times g$ for $1 \mathrm{~min}$ at room temperature. This protocol usually yielded total RNA per

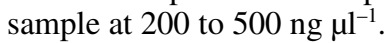

Real-time reverse-transcription polymerase chain reaction viral RNA quantifications. The concentration of nucleic acids in total RNA-preparations was estimated by spectrophotometry and adjusted to $20 \mathrm{ng}^{-1}$ for viral RNA quantification. The amount of viral RNA encoding sequences recognized by specific TaqMan probes was estimated by relative quantification (RQ) real-time reverse-transcription polymerase chain reaction (RT-PCR) or directly by the cycle threshold $\left(\mathrm{C}_{\mathrm{t}}\right)$ values generated without the incorporation of standards in the real-time RT-PCR reaction. RQ was calculated by the $\Delta \Delta \mathrm{C}_{\mathrm{t}}$ method (20) using $18 \mathrm{~S}$ ribosomal RNA as an endogenous reference (Applied Biosystems, Inc., Foster City, CA) and a plant RNA sample with the lowest detectable virus titer as the calibrator. This procedure determined the times a TaqMan-targeted RNA molecule was above the calibrator sample. To estimate the BNYVV RNA-2 titer, primers $50 \mathrm{~F}$ (5'-CCGTTTTCCACAGACACTAACTATGTA-3') and 51R (5'TGCTAACCCTGAATCAGTTAAAGTACTT-3') plus the TaqMan probe NYCP (6FAM-TGCACTTGTGTTATATGTTAATCTGTCTGACCCAG-TAMRA) were incorporated in one-step RTPCR to target the core of the coat protein (CP) gene (2). For detection and quantification of viral RNA-3 encoding specific sequences in the hypervariable coding region of $p 25$, the allelic discrimination primers and 3' minor groove binder TaqMan probes described by Acosta-Leal and Rush (2) were utilized. Real-time reactions were performed by an ABI Prism 7000 system (Applied Biosystems, Inc.) using the following sequential conditions: reverse transcription at $48^{\circ} \mathrm{C}$ for $30 \mathrm{~min}$, reverse transcriptase inactivation at $95^{\circ} \mathrm{C}$ for $10 \mathrm{~min}$, and amplification during 40 cycles of denaturing at $95^{\circ} \mathrm{C}$ for $15 \mathrm{~s}$ and annealing at $60^{\circ} \mathrm{C}$ for $1 \mathrm{~min}$.

RT-PCR, cloning, and sequencing. First-strand cDNA was synthesized using the Omniscript reverse-transcriptase kit (Qiagen, Inc.) according to the manufacturer's recommendations. Total RNA $(0.5 \mu \mathrm{g})$ was denatured at $65^{\circ} \mathrm{C}$ for $5 \mathrm{~min}$ before annealing with $0.5 \mu \mathrm{g}$ of oligo- $\mathrm{dT}_{12-18}$ primer and incubating for cDNA polymerization at $37^{\circ} \mathrm{C}$ for $1 \mathrm{~h}$. PCR was performed in a second tube by incorporating 1 unit per $50-\mu 1$ reaction of Platinum Taq high-fidelity polymerase (Invitrogen, Inc., Carlsbad, CA), $5.0 \mu \mathrm{l}$ of single-stranded cDNA product, primers NYP25-F1 (5'-TTCCTGACCGACCAAATCCA-3') and NYP25-R1 (5'-GTAAACGGACGGGAACACCA-3') at $0.5 \mu \mathrm{M}$ each, and the rest of the reagents at concentrations recommended by the manufacturer. DNA amplification occurred during 30 cycles of denaturing at $94^{\circ} \mathrm{C}$ for $30 \mathrm{~s}$, annealing at $56^{\circ} \mathrm{C}$ for $30 \mathrm{~s}$, and extending at $68^{\circ} \mathrm{C}$ for $1 \mathrm{~min} 30 \mathrm{~s}$. Amplicons were cleaned using the QIAquick kit (Qiagen, Inc.), quantified by spectrophotometry, and submitted for consensus DNA sequencing or recombined with pCR-Blunt (Invitrogen, Inc.) vector for sequencing individual cDNA clones. Plasmid DNA was extracted from individual clones using the QIAprep Spin Miniprep Kit (Qiagen, Inc.). To minimize experimental error, cloned DNA was never exposed to mutagens (i.e., UV or ethidium bromide) and bacterial colonies were not replated. Amplicons and plasmid DNA were sequenced in both directions by a private company (Beckman Coulter Genomics Inc., Beverly, MA) using high-throughput capillary electrophoresis DNA-sequencing instruments.

Viral RNA sequence analyses. The basic processing of cDNA sequences, such as assembling, correction, and alignment, was performed with Lasergene package v8 (Dnastar Inc., Madison, WI), and the chromatograms were inspected with Sequence Scanner v1.0 (Applied Biosystems, Inc.) to verify the presence of mutations. Sequence alignments were saved in Fasta format to be exported into the different applications used in this study. Phylogenetic trees were reconstructed by the neighbor-joining algorithm as implemented in MEGA 3.1 (14). This software was also used to calculate genetic distances between individual sequences and groups of sequences. Genetic differentiation between pairs of populations was statistically estimated by the Wright's $\mathrm{F}_{\mathrm{ST}}$ index of dissimilarity as implemented in Arlequin v.3.11 (5) for haplotypic data. In brief, $\mathrm{F}_{\mathrm{ST}}$ measures the degree of differentiation between two putative subpopulations by comparing the agreement between two haplotypes drawn at random from each subpopulation with the agreement obtained when the haplotypes are taken from the same subpopulation.

\section{RESULTS}

The BNYVV wild-type $\mathrm{A}_{67} \mathrm{C}_{68}$ p25 motif predominates in susceptible sugar beet genotypes from different regions of North America. Phylogenetic analysis of partial RNA-3 consensus sequences of 24 isolates collected from several regions of the United States, and one sequence from France as outgroup, revealed a cluster of nine almost identical BNYVV isolates (i.e., Willmar [MN 2005], wt15 [MN 2000], Salinas [CA 2005], Kammerzal [CO 1999], Idaho [ID 2003], Glendon [MN 2004], Climax [MN 2005], Christian [TX 1991], and TexasKF [TX 2001]) (Fig. 1). These isolates shared the biological feature of having been isolated from severely infected susceptible sugar beet cultivars. Otherwise, they were from different production regions of the country, and collected as much as 14 years apart. Based on this information, these nine isolates were considered contemporary representatives of at least one of the originally introduced wild-type (WT) BNYVV genotypes. At the genomic level, WT isolates encoded alanine and cysteine (i.e., GCU UGU) at the polymorphic amino acid positions 67 and 68 of p25. This $\mathrm{A}_{67} \mathrm{C}_{68}$ amino acid signature was undetected by consensus sequencing of BNYVV isolates collected from resistant $R z l$ plants showing severe symptoms of rhizomania.

Except for Tecker (CA 2005), isolates collected from $R z 1$ resistant plants in CIV encoded leucine instead of cysteine or histidine at position 68 of $p 25$ (Fig. 1). The phylogenetic clustering of these CIV isolates correlated with pathogenicity in $R z 1$ plants. Thus, RB isolates (i.e., DWest149 [CA 2005], Tamarack [CA 2004], Mag10 [CA 2005], Spruce [CA 2005], and Onion [CA 2003]) formed a clade that differentiated from WT CIV isolates (Rockwood [CA 2006], Tuberose [CA 2006], Wtciv [CA 2005], B5 [CA 2006], F5 [CA 2006], and R156 [CA 2003]). As expected from previous studies $(2,12)$, all RB isolates, including Tecker (CA 2005) and those from MN (i.e., Blinker83 [MN 2004] and 
Zimmer [MN 2006]), encoded valine at position 67 of $p 25$ instead of alanine.

Pathogenicity of BNYVV in $R z 1$ plants is associated with a reduction or disappearance of RNA-3 molecules encoding $\mathbf{A}_{67} \mathbf{C}_{68}$. The relative titer of $p 25$ encoding the $\mathrm{A}_{67} \mathrm{C}_{68}$ motif in relation with total BNYVV titer was estimated in asymptomatic (i.e., green plants generally without rhizomania) and symptomatic (i.e., yellow plants with rhizomania) $R z 1$ plants collected from three locations in MN and four fields from CIV during 2005 to 2007. These production regions represent two contrasting pathosystems. In MN, sugar beet crops are grown from April to October, mainly without irrigation and, in addition to BNYVV, the crop frequently is infected by another Benyvirus, Beet soilborne mosaic virus (BSBMV) $(9,26,36)$. In CIV, sugar beet plants are cultivated from September to July under irrigation, and BNYVV is apparently the only Benyvirus present.

Specific TaqMan probes, one targeting the RNA-3 region encompassing the codons GCU and UGU for $\mathrm{A}_{67} \mathrm{C}_{68}$ and another the $\mathrm{CP}$-coding region on RNA-2 (2), were used to estimate WT p25 and total virus titers, respectively. In total, 37 green and 50 yellow plants infected by BNYVV were analyzed. As expected, roots from yellow plants usually contained greater viral RNA-2 titer than green plants (Fig. 2). Statistical comparisons were done between titers of the same targeted RNA sequence from the same sampled location. Except for those bars in Figure 2 with the same letter, the differences in content of the targeted RNA between green and yellow plants were statistically significant $(P<0.001)$. Thus, the difference in RNA-2 titers between green and yellow plants was statistically significant except for the samples from

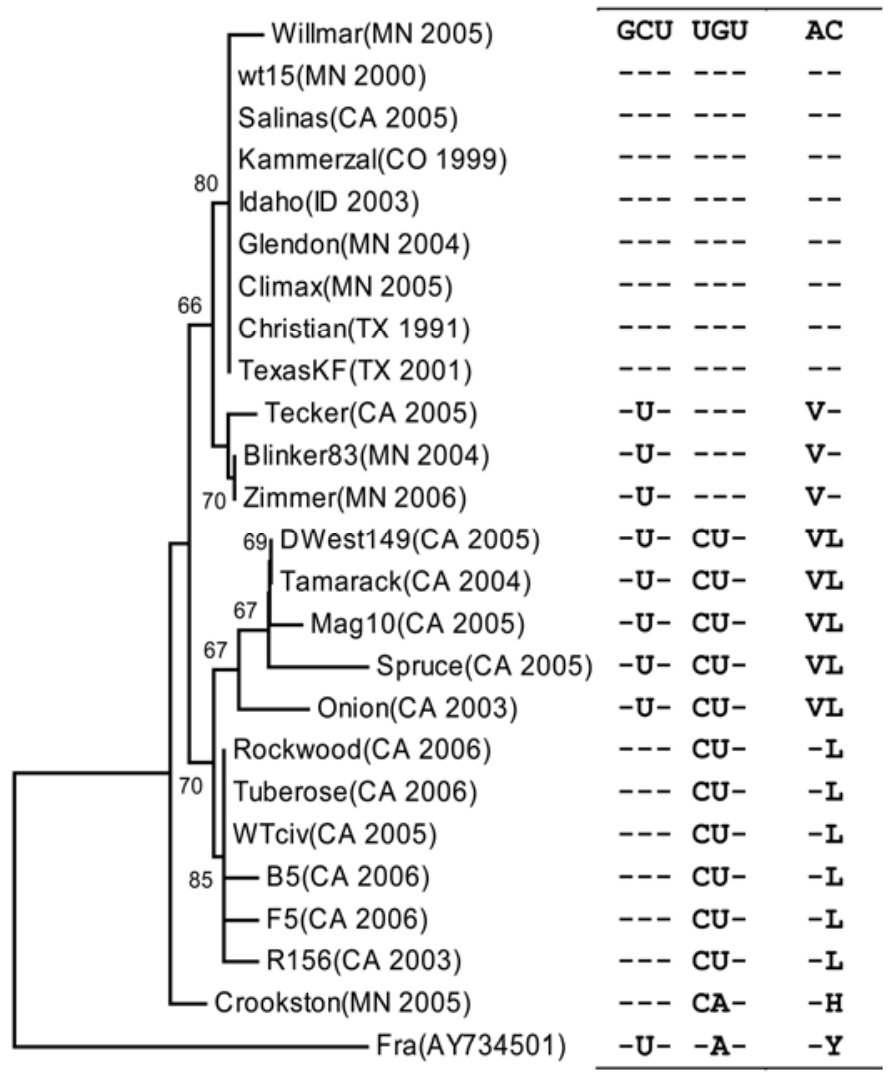

Fig. 1. Phylogram of 24 North American isolates of Beet necrotic yellow vein virus (BNYVV) rooted by an isolate from France (accession no. AY34501) included as outgroup, and their predicted amino acid motif at positions 67 and 68 of $\mathrm{p} 25$.
Willmar, MN (Fig. 2B). Coincidently, only these samples were infected in high incidence by BSBMV, which was co-infecting with BNYVV in $100 \%$ of the green and $60 \%$ of the yellow $R z 1$ plants. Also, BSBMV titer was greater in green than yellow $R z l$ plants (data not shown). These observations support previous

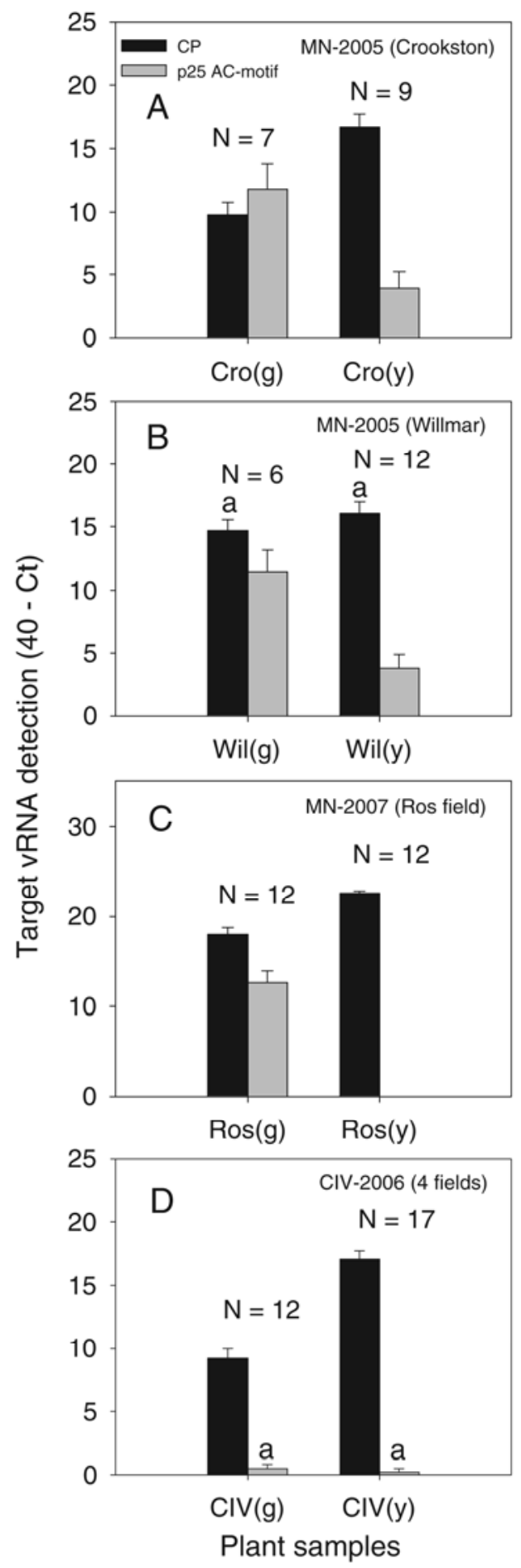

Fig. 2. Relationship between titers of Beet necrotic yellow vein virus (BNYVV) RNA-2 (coat protein [CP] coding region) and RNA-3 encoding $\mathrm{A}_{67} \mathrm{C}_{68}$ in $R z 1$ plants collected from three locations of Minnesota (MN) and four fields from the California Imperial Valley (CIV). Viral RNA (vRNA) titers were semiquantitatively estimated by the cycle threshold values generated by real-time reverse-transcription polymerase chain reaction minus 40 , which was the maximum number of amplification cycles. In this way, the $\mathrm{y}$-axis values are directly proportional to RNA titer. $\mathrm{N}$ is the number of infected green (g) and yellow (y) plants included in the analyses. Bars of the same targeted vRNA from the same location with the same letter are not significantly different $(P>0.05)$. 
reports of an antagonistic interaction between BNYVV and BSBMV $(21,35)$. In this case, BNYVV apparently decreased the incidence of BSBMV in yellow plants. Nevertheless, it also suggests that BNYVV titer increased in green plants (Fig. 2B) as a result of its interaction with BSBMV. Some of these green plants exhibited root symptoms different from the typical rhizomania symptoms.

A greater RNA-2 titer in yellow plants was usually associated with lower titer or disappearance of $\mathrm{A}_{67} \mathrm{C}_{68}$ p25 in the infecting virus population (Fig. 2). This observation suggested that most of these severely infected $R z l$ plants were carrying a different and, consequently, undetected BNYVV p25 motif. Furthermore, by targeting the samples from MN with a TaqMan probe for detection of the $\mathrm{RB} \mathrm{V}_{67} \mathrm{~L}_{68}$ p25 motif (2), it was revealed that these isolates were not carrying this specific $\mathrm{RB}$ allele (data not shown). In CIV, the situation was different; RNA-3 encoding $\mathrm{V}_{67} \mathrm{~L}_{68}$ predominated in yellow plants and its titer was proportional to virus content (Fig. 3A). By contrast, in the surrounding green plants, $\mathrm{V}_{67} \mathrm{~L}_{68}$ p 25 motif was generally undetected or in low concentration regardless of virus titer (Fig. 3B).
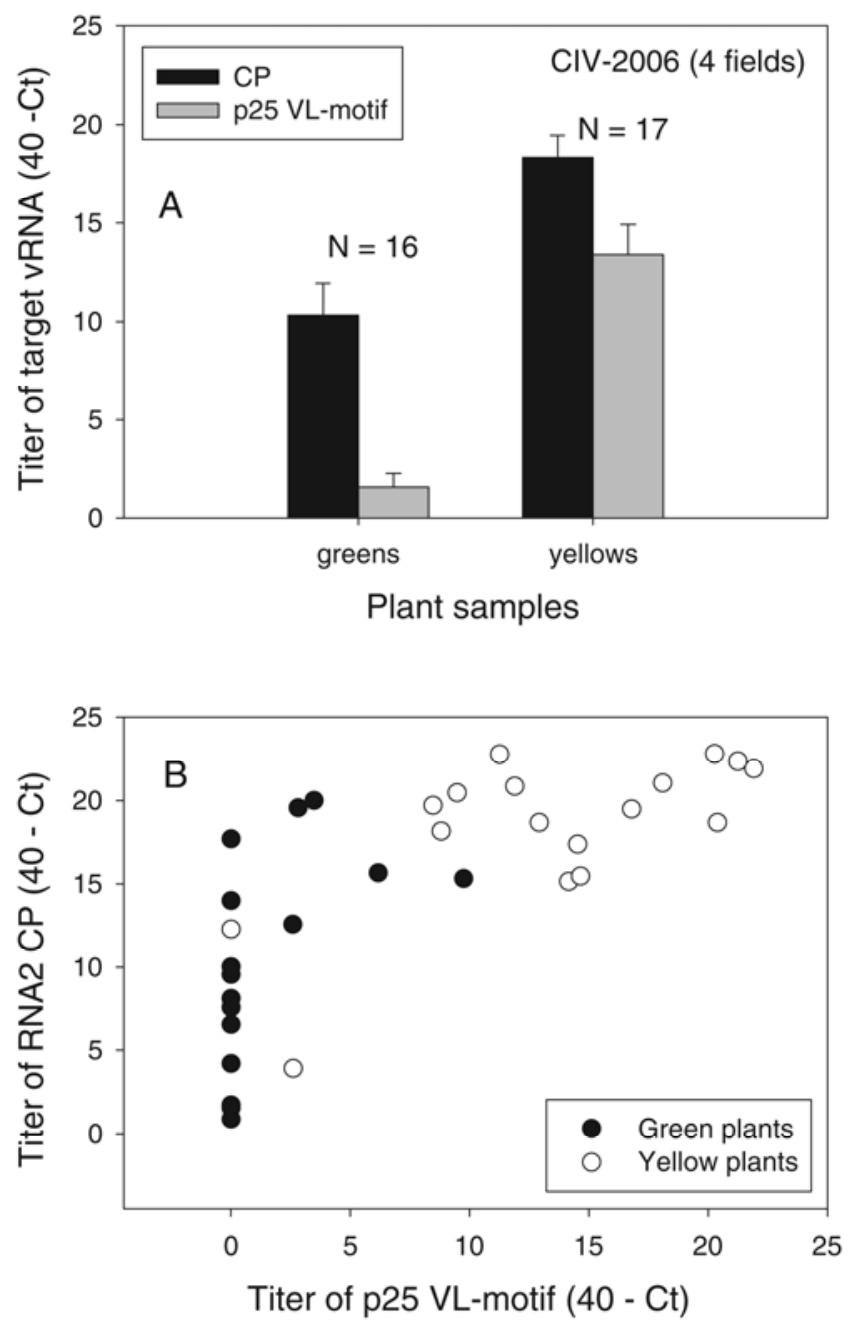

Fig. 3. Relationship between titers of Beet necrotic yellow vein virus (BNYVV) RNA-2 (coat protein [CP] coding region) and RNA-3 encoding $\mathrm{V}_{67} \mathrm{~L}_{68}$ in resistant $R z 1$ plants from the California Imperial Valley (CIV). Viral RNA (vRNA) titers were semiquantitatively estimated by the cycle threshold values generated by real-time reverse-transcription polymerase chain reaction minus 40 , which was the maximum number of amplification cycles. In this way, the $\mathrm{y}$-axis values are directly proportional to RNA titer. $\mathrm{N}$ is the number of infected green ( $\mathrm{g}$ ) and yellow (y) plants included in the analyses. Bars of the same targeted vRNA from the same location with the same letter are not significantly different $(P>0.05)$. A, Mean and standard error of vRNA titers. B, vRNA titers in individual $R z l$ plants.
The same $C$ to $U$ nucleotide substitution in the coding region of $p 25$ is associated with breakdown of $R z 1$-mediated resistance in MN and CIV. Virus titer and consensus DNA sequences of sympatric WT and RB isolates were analyzed to investigate the lack of TaqMan detection of RNA-3 encoding $\mathrm{A}_{67} \mathrm{C}_{68}$ using the GCU UGU codons in yellow plants from MN2007 (Fig. 2C). Green and yellow plants were sampled approximately every meter along an 8- to 10-m transect passing through a yellow spot of diseased plants. The three yellow spots sampled in this way were $\approx 200$ to $400 \mathrm{~m}$ apart in the same field, and two to three isolates from green and yellow plants per transect were randomly selected for amplicon sequencing.

Relative BNYVV quantification by real-time RT-PCR revealed that yellow plants in the center of the yellow spots contained the highest viral RNA-2 titers (RQ $\log _{10}=6.48 \pm 0.64$ ) and green plants located at the extremes of the transects contained the lowest (RQ $\log _{10}=4.89 \pm 1.33$ ) (Fig. 4A). Furthermore, phylo-

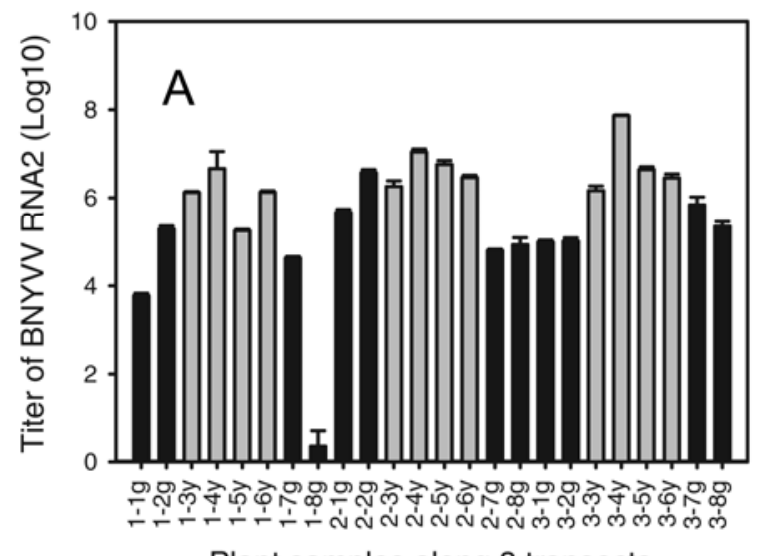

Plant samples along 3 transects

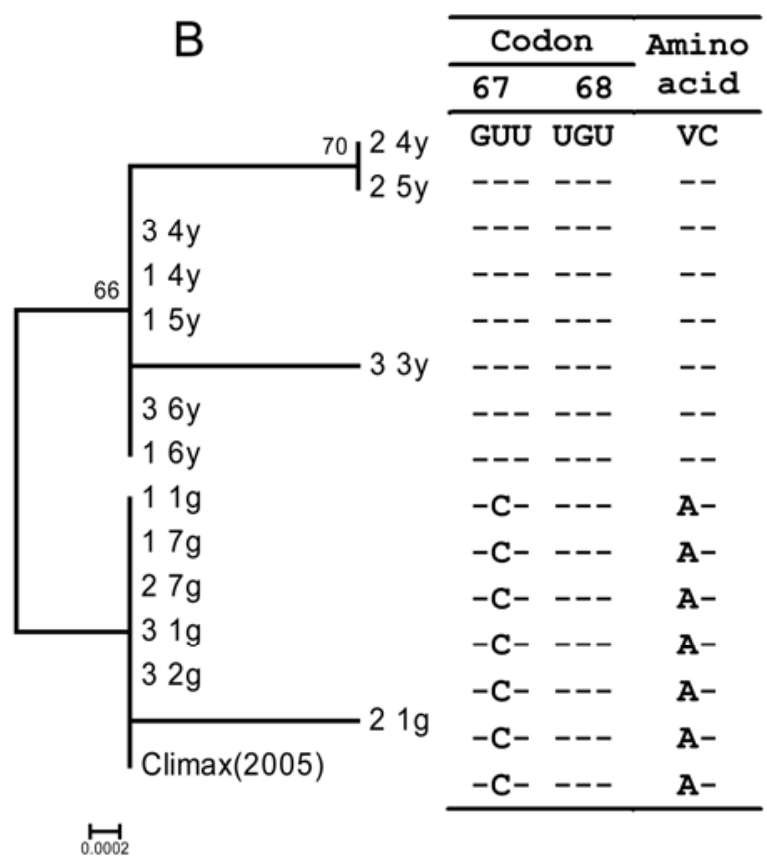

Fig. 4. Relation between virus titer in asymptomatic (g) and symptomatic (y) Rzl plants along three transects and virus genotype in the $p 25$ gene. A, Beet necrotic yellow vein virus (BNYVV) RNA-2 relative quantification by realtime reverse-transcription polymerase chain reaction in asymptomatic (black bars) and symptomatic (gray bars) plants. Titers between asymptomatic and symptomatic plants were statistically different at $P<0.001$. B, Phylogram and polymorphism at codon $67-68$ of the $p 25$ gene revealed after amplicons from two to three asymptomatic and symptomatic plants, chosen at random from each transect, were DNA sequenced. 
genetic analysis indicated that sequences derived from yellow plants configured a separate clade (Fig. 4B). Plants that were close together occasionally were infected by the same consensus RNA-3 sequence that differentiated from the other sequences (e.g., 2-4y and 2-5y). Interestingly, all isolates infecting yellow plants carried the $\mathrm{V}_{67} \mathrm{C}_{68}$ p25 motif whereas all isolates from green plants codified for $\mathrm{WT}_{\mathrm{A}_{67}} \mathrm{C}_{68}$. The genetic change behind this amino acid shift was a nucleotide transition from $\mathrm{C}$ to $\mathrm{U}$ at codon 67 (Fig. 4B). Thus, the same mutation observed in RB variants from $\mathrm{MN}$ and CIV (Fig. 1) accounted for the capability of BNYVV to cause rhizomania in the sampled yellow patches from MN-2007.

Asymptomatic plants in CIV are mostly infected by a distinct WT BNYVV genotype. Despite the ample dispersion of WT $\mathrm{A}_{67} \mathrm{C}_{68}$ p25 motif in North America, these genotypes were scarcely detected in green Rzl plants from CIV (Fig. 2D). Previously, we observed that most asymptomatic infections were caused by WT BNYVV isolates encoding the $\mathrm{A}_{67} \mathrm{~L}_{68}$ p25 motif (2). Also, in this particular pathosystem, a polymorphism at amino acid position 135 of $p 25$ was associated with pathogenesis. To determine the genetic composition of WT BNYVV populations in CIV, viral RNA-3 cDNA clones derived from nine asymptomatic Rzl plants were sequenced. Viral RNA-3 encoding WT $\mathrm{A}_{67} \mathrm{C}_{68} \mathrm{D}_{135}$ was found in just one plant, and it was coinfecting with molecules encoding $\mathrm{V}_{67} \mathrm{~L}_{68} \mathrm{E}_{135}$ (Table 1). As expected, the WT $\mathrm{A}_{67} \mathrm{~L}_{68} \mathrm{D}_{135}$ p25 was detected alone in $78 \%$ of the plant samples. Also, RB haplotypes with the $\mathrm{V}_{67} \mathrm{~L}_{68} \mathrm{E}_{135}$ signature were detected only in the isolate $\mathrm{Tub}(7 \mathrm{~g})$. This may have resulted from a recent $\mathrm{RB}$ infection that later may have developed typical disease symptoms.

RB variants from MN and CIV apparently originated from different BNYVV lineages during independent events. Except for BNYVV-Tecker, the phylogenetic differentiation between isolates from CIV and other parts of the United States (Fig. 1), along with the high similarity between WT and RB isolates from MN (Fig. 4B), suggested that the determinant mutation to overcome $R z l$ occurred in parallel between CIV and MN groups of isolates (i.e., the occurrence of same nucleotide substitutions at the same site in two or more independent lineages) (8). To test this hypothesis, genetic distances between WT and RB isolates from both regions were more precisely estimated. Consensus sequences of isolates from CIV and MN used for Figure 1 and all sequences used for Figure $4 \mathrm{~B}$ were grouped according to their pathogenicity in $R z 1$ plants to form the groups $\mathrm{WT}_{\mathrm{MN}}, \mathrm{WT}_{\mathrm{CIV}}$, $\mathrm{RB}_{\mathrm{MN}}$, and $\mathrm{RB}_{\mathrm{CIV}}$. Then, the average number of nucleotide differences and percentage of genetic differences was calculated between these four groups. This populational analysis revealed that $\mathrm{WT}$ and $\mathrm{RB}$ isolates from $\mathrm{MN}$ were more closely related to each other (i.e., $1.8 \pm 1.0$ nucleotide differences) than to either of

TABLE 1. Number of Beet necrotic yellow vein virus (BNYVV) haplotypes with specific amino acid motif in p25 (positions 67, 68, and 135) detected in isolates from asymptomatically infected $R z 1$ sugar beet plants from California Imperial Valley

\begin{tabular}{lcccc}
\hline & \multicolumn{3}{c}{ BNYVV p25 motif } & \\
\cline { 2 - 4 } Isolate & ACD & ALD & VLE & Total per plant \\
\hline $\operatorname{RocS}(1 \mathrm{~g})$ & 0 & 7 & 0 & 7 \\
$\operatorname{RocS}(2 \mathrm{~g})$ & 0 & 4 & 9 & 13 \\
$\operatorname{RocN}(1 \mathrm{~g})$ & 4 & 0 & 5 & 9 \\
$\operatorname{RocN}(2 \mathrm{~g})$ & 0 & 3 & 0 & 3 \\
$\operatorname{RocN}(9 \mathrm{~g})$ & 0 & 6 & 0 & 6 \\
Tri(2g) & 0 & 2 & 0 & 2 \\
Tub(2g) & 0 & 8 & 0 & 8 \\
Tub(7g) & 0 & 0 & 8 & 8 \\
Tub(8g) & 0 & 8 & 0 & 8 \\
Total per motif & 4 & 38 & 22 & $64^{\mathrm{a}}$
\end{tabular}

a Total number of sequenced cDNA clones derived from viral RNA isolated from asymptomatic lateral roots of individual $R z 1$ sugar beet plants. the two groups from CIV (i.e., 3.4 to 5.6 nucleotide differences) (Table 2). Similarly, RB isolates from CIV were more closely related to WT isolates from the same region than to any isolate from MN.

\section{DISCUSSION}

This study revealed that BNYVV isolates infecting susceptible sugar beet genotypes, which lack the dominant $R z 1$ allele, encode the amino acids $\mathrm{A}_{67} \mathrm{C}_{68} \mathrm{D}_{135}$ in p25 (RNA-3) in most sugar beet production regions of the United States. Apparently, this consensus WT genotype has been maintained with minimal variation since 1991, before the massive commercialization of $R z l$ cultivars. Also, WT BNYVV was consistently found in asymptomatic $R z 1$ plants from $\mathrm{MN}$ and some production areas in California. However, in CIV, most WT isolates encoded $\mathrm{A}_{67} \mathrm{~L}_{68} \mathrm{D}_{135}$ instead of $\mathrm{A}_{67} \mathrm{C}_{68} \mathrm{D}_{135}$. It is unknown whether $p 25$ evolved in CIV from $\mathrm{A}_{67} \mathrm{C}_{68} \mathrm{D}_{135}$ to $\mathrm{A}_{67} \mathrm{~L}_{68} \mathrm{D}_{135}$ or if both were independently introduced into this region.

Isolates from the groups $\mathrm{WT}_{\mathrm{MN}}$ (i.e., encoding $\mathrm{A}_{67} \mathrm{C}_{68} \mathrm{D}_{135}$ ) and $\mathrm{WT}_{\text {CIV }}$ (i.e., encoding $\mathrm{A}_{67} \mathrm{~L}_{68} \mathrm{D}_{135}$ ) differed from each other by $\approx 3.4$ fixed nucleotide substitutions in the $p 25$ gene (Table 2). Two of these mutations occurred at codon 68 where they caused an amino acid replacement that is under strong diversifying selection $(1,28)$ but the effect of this amino acid change on virus fitness is unknown. Surprisingly, the same nucleotide $\mathrm{C}$ to $\mathrm{U}$ substitution at codon 67 , which confers to BNYVV the capability to overcome $R z 1$ in greenhouse assays (12), was identified in RB strains from two distantly separated and contrasting pathosystems in the United States. The fact that this nucleotide substitution was a $C$ to $\mathrm{U}$ transition in a hypervariable region suggests that $\mathrm{RB}$ variants could easily originate multiple times by convergent evolution, which may explain the reduced durability of $R z l$-mediated resistance in the field.

At least two possible evolutionary scenarios could explain the origin of $\mathrm{RB}$ isolates encoding $\mathrm{V}_{67} \mathrm{C}_{68} \mathrm{D}_{135}$ ( $\mathrm{RB}_{\mathrm{MN}}$ group) and $\mathrm{V}_{67} \mathrm{~L}_{68} \mathrm{E}_{135}$ ( $\mathrm{RB}_{\mathrm{CIV}}$ group). In the first scenario, the determinant $\mathrm{A}_{67} \mathrm{~V}$ amino acid substitution may have originated in a common p25 ancestor and then diversified in $R z 1$ plants into $\mathrm{V}_{67} \mathrm{C}_{68} \mathrm{D}_{135}$ in $\mathrm{MN}$ and $\mathrm{V}_{67} \mathrm{~L}_{68} \mathrm{E}_{135}$ in CIV. In the second scenario, RB progenitors of the $\mathrm{RB}_{\mathrm{MN}}$ and $\mathrm{RB}_{\mathrm{CIV}}$ groups derived directly from WTs $\mathrm{A}_{67} \mathrm{C}_{68} \mathrm{D}_{135}$ and $\mathrm{A}_{67} \mathrm{~L}_{67} \mathrm{E}_{135}$ isolates, respectively, by a single parallel nucleotide substitution. The first hypothesis is less likely because it requires a greater number of mutational events (6) (Table 2), whereas the second hypothesis only involves a single parallel $\mathrm{C}$ to $\mathrm{U}$ nucleotide substitution in the hypervariable coding region of $p 25$. Although WT isolates encoding $\mathrm{A}_{67} \mathrm{~L}_{68} \mathrm{D}_{135}$ have

TABLE 2. Genetic distances between wild-type (WT) and resistance-breaking (RB) groups of Beet necrotic yellow vein virus (BNYVV) isolates collected from California Imperial Valley (CIV) and Minnesota (MN)

\begin{tabular}{|c|c|c|}
\hline \multirow[b]{2}{*}{ Pairwise comparison } & \multicolumn{2}{|c|}{ Nucleotide differences $( \pm \mathrm{SE})^{\mathrm{a}}$} \\
\hline & Number & Percent \\
\hline $\mathrm{WT}_{\mathrm{CIV}}$ versus $\mathrm{WT}_{\mathrm{MN}}$ & $3.40 \pm 1.40$ & $0.35 \pm 0.14$ \\
\hline $\mathrm{WT}_{\mathrm{CIV}}$ versus $\mathrm{RB}_{\mathrm{MN}}$ & $4.40 \pm 1.72$ & $0.45 \pm 0.17$ \\
\hline $\mathrm{WT}_{\mathrm{CIV}}$ versus $\mathrm{RB}_{\mathrm{CIV}}$ & $4.08 \pm 1.42$ & $0.42 \pm 0.15$ \\
\hline $\mathrm{WT}_{\mathrm{MN}}$ versus $\mathrm{RB}_{\mathrm{MN}}$ & $1.80 \pm 1.00$ & $0.18 \pm 0.10$ \\
\hline $\mathrm{WT}_{\mathrm{MN}}$ versus $\mathrm{RB}_{\mathrm{CIV}}$ & $5.65 \pm 1.92$ & $0.58 \pm 0.19$ \\
\hline $\mathrm{RB}_{\mathrm{MN}}$ versus $\mathrm{RB}_{\mathrm{CIV}}$ & $4.65 \pm 1.70$ & $0.48 \pm 0.17$ \\
\hline \multicolumn{3}{|c|}{$\begin{array}{l}\text { Each isolate was represented by the consensus sequence of a } 975 \text {-nucleotide } \\
\text { fragment encompassing the complete } p 25 \text { gene and adjacent } 3^{\prime} \text { untranslated } \\
\text { regions in } \mathrm{RNA}^{2} 3 \text {. In total, } 10,10,6 \text {, and } 4 \text { isolates were grouped in } \\
\mathrm{WT}_{\mathrm{MN}}, \mathrm{RB}_{\mathrm{MN}}, \mathrm{WT}_{\mathrm{CIV}} \text {, and } \mathrm{RB}_{\mathrm{CIV}} \text {, respectively. Average genetic distances } \\
\text { between groups, estimated by number of nucleotide differences and } \\
\text { percentage of nucleotide differences, were calculated by MEGA } 3.1(14) \text {; } \\
\mathrm{SE}=\text { standard error. All four groups were genetically different }(P \leq 0.005) \text { to } \\
\text { each other based on the } \mathrm{F}_{\mathrm{ST}} \text { index of dissimilarity calculated by Arlequin } \\
\text { version } 3.11(5) \text {. }\end{array}$} \\
\hline
\end{tabular}


not been found in CIV, RB isolates encoding $\mathrm{V}_{67} \mathrm{~L}_{68} \mathrm{E}_{135}$ were recently detected in CIV (unpublished data). This suggests that BNYVV may have evolved in this region from WT $\mathrm{A}_{67} \mathrm{~L}_{68} \mathrm{D}_{135}$ to RB $\mathrm{V}_{67} \mathrm{~L}_{68} \mathrm{D}_{135}$ and then to $\mathrm{V}_{67} \mathrm{~L}_{68} \mathrm{E}_{135}$. This possibility is supported by the observation that positive selection was detected on the replacement of aspartic acid by glutamic acid at position 135 of $p 25$ (1).

Strong selection pressure, such as the widespread introduction of resistant cultivars, seems to favor the occurrence of parallel mutations in individual virus populations. Parallel mutations have been detected in high frequency during host adaptation of phage cultures (34), and parallel mutations better explained the ability of two groups of Potato virus $\mathrm{X}$ strains to overcome $\mathrm{Nb}$ mediated potato resistance (22). Therefore, it is possible that the $\mathrm{A}_{67} \mathrm{~V}$ amino acid substitution in BNYVV isolates from MN and CIV might have occurred in parallel. Genetic analyses of a larger number of sympatric WT and RB isolates from around the world may clarify this issue, and also may reveal a greater number of alternative mechanisms by which BNYVV overcomes $R z 1$.

At present, it appears that the mutational options for BNYVV to overcome $R z 1$ resistance are limited. However, in other virusplant interactions, the mutational choices to overcome host resistance are greater. For instance, a number of amino acid substitutions in the central region of the $V P g$ gene in Rice yellow mottle virus can result in RB isolates (24). Likewise, different mutations in the $\mathrm{CP}$ of $\mathrm{RB}$ isolates of Pepper mild mottle virus allow it to overcome the dominant $L^{3}$-mediated resistance (33). The agricultural importance of this study is that a high frequency of newly emerging RB variants of BNYVV will drastically limit the useful duration of $R z l$ cultivars in the field.

Initially, we hypothesized that $\mathrm{A}_{67}$ in p25 was the elicitor of a generalized BNYVV-induced $R z l$-mediated resistance, as has been previously reported in other incompatible gene-for-gene interactions, including viruses (30). However, the following observations in this particular BNYVV-Rz1 interaction suggest that $\mathrm{A}_{67}$ is not eliciting a generalized defense response. First, viral haplotypes encoding alanine or valine at position 67 of p25 can coinfect the same Rzl plant and rhizomania is still expressed. Second, no amino acid other than valine at position 67 has been associated with the ability of BNYVV to overcome $R z 1$. Therefore, a specific p25-Rz1 interaction may be required for disease development rather than defense activation. This putative p25-Rz1 interaction could be necessary, for instance, to deactivate or delay Rzl-mediated defense responses. Viral suppression of gene silencing is the best example of molecular virus-plant recognition leading to plant susceptibility (16). However, similar recognition events may suppress some other defense mechanisms (23). Given the dominant inheritance of $R z l$-mediated resistance, it is possible that the recessive $r z l$ allele either lacks or encodes a defective defense mechanism. This could explain why susceptible rz1 plants can be severely infected by haplotypes of BNYVV that encode alanine and several other amino acids, including valine, at position 67 of $\mathrm{p} 25$. Thus, in this compatible plant-virus interaction, the specific p25-rz1 molecular coupling might be unnecessary for the virus to cause severe infection.

\section{ACKNOWLEDGMENTS}

This work was funded in part by grants from the Beet Sugar Development Foundation, the Minnesota and North Dakota Research and Education Board, and the United States Department of AgricultureNRI (grant no. 2008-35319-04472). We thank M. Bredehoeft (Southern Minnesota Beet Sugar Cooperative) and A. Cattanach (American Crystal Sugar Company) for their support and advice during field surveys, and M. J. Smith (Texas AgriLife Research) for critical reading of the manuscript.

\section{LITERATURE CITED}

1. Acosta-Leal, R., Fawley, M. W., and Rush, C. M. 2008. Changes in the intraisolate genetic structure of Beet necrotic yellow vein virus populations associated with plant resistance breakdown. Virology 376:6068.

2. Acosta-Leal, R., and Rush, C. M. 2007. Mutations associated with resistance-breaking isolates of Beet necrotic yellow vein virus and their allelic discrimination using TaqMan technology. Phytopathology 97:325330.

3. Acosta-Leal, R., and Xiong, Z. G. 2008. Complementary functions of two recessive $R$-genes determine resistance durability of tobacco 'Virgin A Mutant' (VAM) to Potato virus $Y$. Virology 379:275-283.

4. Burketová, L., Štillerová, K., and Feltlová, M., 2003. Immunohistological localization of chitinase and beta-1,3-glucanase in rhizomania-diseased and benzothiadiazole treated sugar beet roots. Physiol. Mol. Plant Pathol. 63:47-54.

5. Excoffier, L., Laval, G., and Schneider, S. 2005. Arlequin ver. 3.0: An integrated software package for population genetics data analysis. Evol. Bioinf. Online 1:47-50.

6. Felsenstein, J. 2004. Inferring Phylogenies. Sinauer Associates, Inc., Sunderland, MA.

7. García-Arenal, F., and McDonald, B. A. 2003. An analysis of the durability of resistance to plant viruses. Phytopathology 93:941-952.

8. Graur, D., and Li, W.-H. 2000. Fundamentals of Molecular Evolution, 2nd ed. Sinauer Associates, Inc., Sunderland, MA.

9. Heidel, G. B., Rush, C. M., Kendall, T. L., Lommel, S. A., and French, R. C. 1997. Characteristics of Beet soilborne mosaic virus, a furo-like virus infecting sugar beet. Plant Dis. 81:1070-1076.

10. Klein, E., Link, D., Schirmer, A., Erhardt, M., and Gilmer, D. 2007. Sequence variation within Beet necrotic yellow vein virus p 25 protein influences its oligomerization and isolate pathogenicity on Tetragonia expansa. Virus Res. 126:53-61.

11. Koenig, R., and Lennefors, B. L. 2000. Molecular analyses of European $\mathrm{A}, \mathrm{B}$ and $\mathrm{P}$ type sources of Beet necrotic yellow vein virus and detection of the rare P type in Kazakhstan. Arch. Virol. 145:1561-1570.

12. Koenig, R., Loss, S., Specht, J., Varrelmann, M., Lüddecke, P., and Deml, G. 2009. A single U/C nucleotide substitution changing alanine to valine in the Beet necrotic yellow vein virus P25 protein promotes increased virus accumulation in roots of mechanically inoculated, partially resistant sugar beet seedlings. J. Gen. Virol. 90:759-763.

13. Koenig, R., Lüddecke, P., and Haeberlé, A. M., 1995. Detection of Beet necrotic yellow vein virus strains, variants and mixed infections by examining single-strand conformation polymorphisms of immunocapture RT-PCR products. J. Gen. Virol. 76:2051-2055.

14. Kumar, S., Tamura, K., and Nei. M. 2004. MEGA3: Integrated software for molecular evolutionary genetics analysis and sequence alignment. Brief. Bioinf. 5:150-163.

15. Larson, R. L., Wintermantel, W. M., Hill, A., Fortis, L., and Nuñez, A. 2008. Proteome changes in sugar beet in response to Beet necrotic yellow vein virus. Physiol. Mol. Plant Pathol. 72:62-72.

16. Levy, A., Dafny-Yelin, M., and Tzfira, T. 2008. Attacking the defenders: plant viruses fight back. Trends Microbiol. 16:194-197.

17. Link, D., Schmidlin, L., Schirmer, A., Klein, E., Erhardt, M., Geldreich, A., Lemaire, O., and Gilmer, D. 2005. Functional characterization of the Beet necrotic yellow vein virus RNA-5-encoded $\mathrm{p} 26$ protein: evidence for structural pathogenicity determinants. J. Gen. Virol. 86:2115-2125.

18. Liu, H. Y., and Lewellen, R. T. 2007. Distribution and molecular characterization of resistance-breaking isolates of Beet necrotic yellow vein virus in the United States. Plant Dis. 91:847-851.

19. Liu, H. Y., Sears, J. L., and Lewellen, R. T. 2005. Occurrence of resistance-breaking Beet necrotic yellow vein virus of sugar beet. Plant Dis. 89:464-468

20. Livak, K. J. and Schmittgen, T. D. 2001. Analysis of relative gene expression data using real-time quantitative PCR and $2^{-\Delta \Delta C t}$ method. Methods 25:402-408.

21. Mahmood, T., and Rush, C. M. 1999. Evidence of cross-protection between Beet soilborne mosaic virus and Beet necrotic yellow vein virus in sugar beet. Plant Dis. 83:521-526.

22. Malcuit, I., de Jong, W., Baulcombe, D. C., Shields, D. C., and Kavanagh, T. A. 2000. Acquisition of multiple virulence/avirulence determinants by Potato virus $X(\mathrm{PVX})$ has occurred through convergent evolution rather than through recombination. Virus Genes 20:165-172.

23. Maule, A., Leh, V., and Lederer, C. 2002. The dialogue between viruses and hosts in compatible interactions. Curr. Opin. Plant Biol. 5:279-284.

24. Pinel-Galzi, A., Rakotomalala, M., Sangu, E., Sorho, F., Kanyeka, Z., Traoré, O., Sereme, D., Poulicard, N., Rabenantoandro, Y., Séré, Y., Konaté, G., Ghesquiere, A., Hébrard, E., and Fargette, D. 2007. Theme and variations in the evolutionary pathways to virulence of an RNA plant virus species-Art. No. e180. Plos Pathog. 3:1761-1770. 
25. Rahim, M. D., Andika, I. B., Han, C., Kondo, H., and Tamada, T. 2007. RNA4-encoded p31 of Beet necrotic yellow vein virus is involved in efficient vector transmission, symptom severity and silencing suppression in roots. J. Gen. Virol. 88:1611-1619.

26. Rush, C. M. 2003. Ecology and epidemiology of benyviruses and plasmodiophorid vectors. Annu. Rev. Phytopathol. 41:567-592.

27. Rush, C. M., Liu, H. Y., Lewellen, R. T., and Acosta-Leal, R. 2006. The continuing saga of rhizomania of sugar beets in the United States. Plant Dis. 90:4-15.

28. Schirmer, A., Link, D., Cognat, V., Moury, B., Beuve, M., Meunier, A., Bragard, C., Gilmer, D., and Lemaire, O. 2005. Phylogenetic analysis of isolates of Beet necrotic yellow vein virus collected worldwide. J. Gen. Virol. 86:2897-2911.

29. Schmidlin, L., De Bruyne, E., Weyens, G., Lefebvre, M., and Gilmer, D. 2008. Identification of differentially expressed root genes upon rhizomania disease. Mol. Plant Pathol. 9:741-751.

30. Soosaar, J. L. M., Burch-Smith, T. M., and Dinesh-Kumar, S. P. 2005. Mechanisms of plant resistance to viruses. Nat. Rev. Microbiol. 3:789798.
31. Tamada, T. 2002. Beet necrotic yellow vein virus. In: Descriptions of Plant Viruses. AAB, www.dpvweb.net/dpv.

32. Tamada, T., Uchino, H., Kusume, T., and Saito, M. 1999. RNA 3 deletion mutants of Beet necrotic yellow vein virus do not cause rhizomania disease in sugar beets. Phytopathology 89:1000-1006.

33. Tsuda, S., Kirita, M., and Watanabe, Y. 1998. Characterization of a Pepper mild mottle tobamovirus strain capable of overcoming the L-3 genemediated resistance, distinct from the resistance-breaking Italian isolate. Mol. Plant-Microbe Interact. 11:327-331.

34. Wichman, H. A., Badgett, M. R., Scott, L. A., Boulianne, C. M., and Bull, J. J. 1999. Different trajectories of parallel evolution during viral adaptation. Science 285:422-424.

35. Wisler, G. C., Lewellen, R. T., Sears, J. L., Wasson, J. W., Liu, H. Y., and Wintermantel, W. M. 2003. Interactions between Beet necrotic yellow vein virus and Beet soilborne mosaic virus in sugar beet. Plant Dis. 87:1170-1175.

36. Workneh, F., Villanueva, E., Steddom, K., and Rush, C. M. 2003. Spatial association and distribution of Beet necrotic yellow vein virus and Beet soilborne mosaic virus in sugar beet fields. Plant Dis. 87:707-711. 